\& J. Edu. \& Sci., Vol. (24), No. (4) 2011 \&

\title{
Spectrophotometic Determination of Isoniazid (INH) \\ Using 2,4-dinitro-1-flourobenzene (DNFB) - Application to Tablet
}

\author{
Hayfa M. Jassim Al-Hammoshi \\ Department of Chemistry / College of Science \\ University of Mosul
}

Received

23 / 05 / 2010
Accepted

14 / 09 / 2010

\section{الخلاصة: 20 - 20}

نم تطوير طريقة طيفية سهلة لتقدير كميات مايكرو غرامي ة من عقار الايزونيازايد في الاقراص الدوائية وتعتمد الطريقة على التفاعل بين الايزونزايد والكاشف (2,4-ثنائي نيترو - 1-

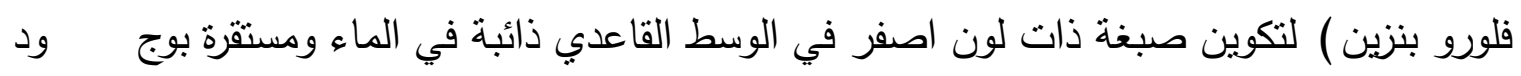

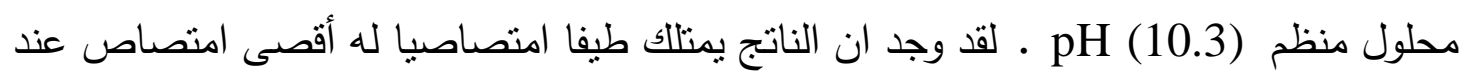

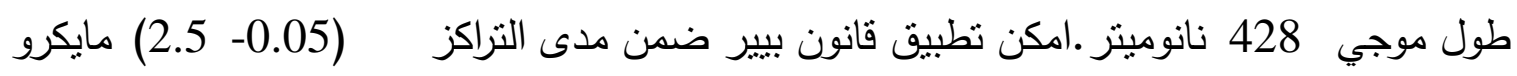

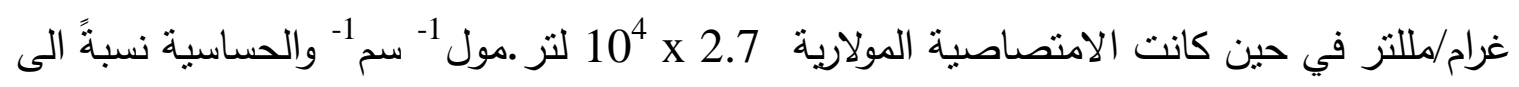

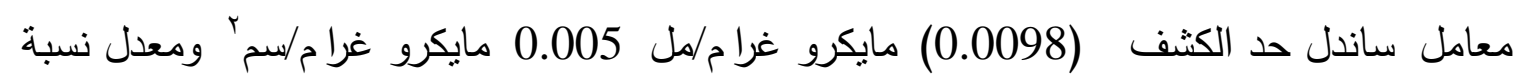

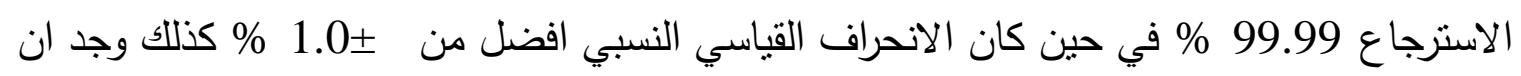

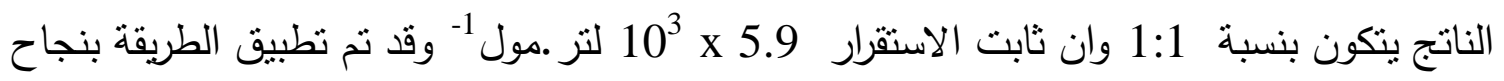

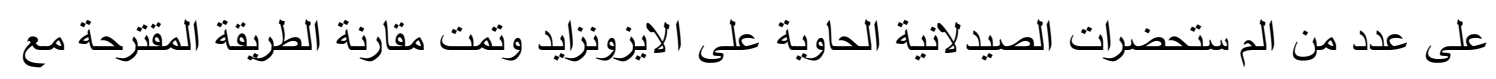
الطريقة المعتمدة في دستور الادوية البريطاني.

\section{Abstract}

A rapid, simple, reproducible and sensitive spectrohpotometric method for assay of (INH) was investigated. The method is based on the reaction of INH with 2,4-dinitro-1-flourobenzene reagent to give a highly colored species with maximum at $\lambda 428 \mathrm{~nm}$ in aqueous medium of $\mathrm{pH} 10.3$. Beer's law was obeyed in the range of $(0.05-2.5) \mu \mathrm{g} / \mathrm{ml}$ with a molar 
absorptivity $2.7 \times 10^{4} 1 . \mathrm{mol} \mathrm{l}^{-1} \mathrm{~cm}^{-1}$.The sandell index was $0.005 \mu \mathrm{g} . \mathrm{cm}^{-2}$ and the limit of detection was $0.00984 \mu \mathrm{g} / \mathrm{ml}$. The accuracy (average recovery\%) was $99.99 \%$ and the relative standard deviation (RSD) was better than $\pm 1.0 \%$. Also it was found that the product formed was in a ratio of $1: 1$ with a stability constant of $5.9 \times 10^{3} 1 . \mathrm{mol}^{-1}$. The method was applied successfully to assay INH in pharmaceutical formulations and agreed well with its certified value and the British pharmacopoeia method.

Keywords: Spectrophotometric; Isoniazid; DNFB.

\section{Introduction}

Pyridine - 4 - carboxylic acid hydrazide [I] commercially known as isoniazid is an important drug compound for the chemotherapy of tuberculosis and is widely used together with rifampicin and streptomycin ${ }^{(1)}$. This prompted many investigators to devise methods for the rapid determination of isoniazid in its pure form as well as pharmaceutical preparations.<smiles>NNC(=O)c1ccncc1</smiles>

$$
\begin{array}{cl}
\mathrm{H} & \mathrm{M} \cdot \mathrm{Wt}=137.1 \mathrm{~g} / \mathrm{mol} \\
\mathrm{C}_{6} \mathrm{H}_{7}{ }_{7} \mathrm{~N}_{3} \mathrm{O} & \mathrm{m} \cdot \mathrm{p}=170-174{ }^{\circ} \mathrm{C}
\end{array}
$$

Many analytical techniques have been proposed for the determination of isoniazid including fluorescence ${ }^{(2,3)}$, electroanalytical ${ }^{(4)}$, flow-injection chemiluminescene methods ${ }^{(5)}$, titrations ${ }^{(6,7)}$, atomic absorption spectrometry ${ }^{(8,9)}$ chromatography ${ }^{(10)}$, capillaryelectrophoresis ${ }^{(11,12)}$ and $\mathrm{H}^{1}$ NMR spectroscopy ${ }^{(13)}$. The above mentioned techniques are sensitive but expensive, Specetrophotometry ${ }^{(14,15)}$ is still the technique of choice even today due to inherent simplicity.

In the literature many spectrophotometric procedure have been applied for the determination of isoniazid using different reagents including 6-meythyl -2-pyridine carboxaldehyde as a derivatizing reagent ${ }^{(16)}, 1,2,4$ aminonaphtholsulphonic acid $^{(17)}$, 6,7-dichloroquinoline-5,8-dione ${ }^{(18)}$, 4,4sulphonyldianiline as a coupling agent ${ }^{(19)}$, and using molybdenum(VI) in acidic medium as an oxidizing agent ${ }^{(20)}$ in addition to other spectrophotometric methods ${ }^{(21,22,23)}$. 
The British pharmacopoeia ${ }^{(24)}$ atitrimetric reported method using potassium bromate solution as atitrant in acidic medium for determination of isoniazid as a pure powder and in tablets and requires about $0.25 \mathrm{~g}$ of the drug. However 2,4-dinitro-1-flourobenzene (DNFB), so called Snager's reagent, has been used as achromogenic reagent for the spectrophotometric determination of amino acids primary and secondary amines ${ }^{(25-29)}$, amino acid nitrogen in plasma and urine ${ }^{(30,31)}$, isoniazid ${ }^{(32)}$, various amino glycoside, antibiotics (gentamycin, torbomycin, amikacin) ${ }^{(33)}$, phenols ${ }^{(34)}$ and the enzyme amidase ${ }^{(35)}$. It has also been used in high-performance liquid chromatography for the determination of amines and aminoglycocides and in thin layer chromatography ${ }^{(36-38)}$. However these methods lack selectivity.

In this paper the employment of (DNFB) as achromogenic reagent for simple, sensitive, selective, rapid, accurate, precise and inexpensive method for determination of isoniazid in pure powder and pharmaceutical preparation is described.

\section{Materials and Methods}

\section{Apparatus and reagents}

Shimadzu (UV-210) double beam spectrophotometer with $1.0 \mathrm{~cm}$ silica cells was used to measure the absorbance and graduated pipettes were employed. Analytical grade chemicals and distilled water were used. Isoniazid (State Company for Drug Industries and Medical Appliances, Sammara-Iraq) standard solution $(100 \mu \mathrm{g} / \mathrm{ml})$ was prepared in distilled water to get a stock solution, which was diluted further as required, while $1 \times 10^{-2} \mathrm{M}$ of DNFB (Sigma Co.) and buffer solution of $\mathrm{pH} 10.3^{(39)}$ buffer solution was prepared from (sodium hydroxide and borate).

\section{Reagents}

DNFB (2,4-dinitro-1-flourobenzene) $\left(\begin{array}{lllll}1 & \mathrm{x} & 10^{-2} & \mathrm{M}\end{array}\right)$ solution was prepared daily by dissolving accurately $0.186 \mathrm{~g}$ of DNFB in about $5 \mathrm{ml}$ ethanol then transferred to $100 \mathrm{ml}$ volumetric flask and diluted to the mark by distilled water (the prepared solution is stable for several days if stored in a cool and dark place).

\section{Buffer solution (pH 10.3)}

The buffer was prepared by transferring $50 \mathrm{ml}$ of $0.025 \mathrm{M}$ solution of sodium tetraborate and $21.3 \mathrm{ml}$ of $0.1 \mathrm{M}$ solution of sodium hydroxide into $100 \mathrm{ml}$ volumetric flask then diluted to the mark with distilled water. 


\section{General Procedure}

Aliquots and calibration graph containing 0.05 to $2.5 \mathrm{ml}(25 \mu \mathrm{g} / \mathrm{ml})$ of INH were transferred into a series of $25-\mathrm{ml}$ standard flasks, followed by addintion of $2 \mathrm{ml}$ of $1 \times 10^{-2} \mathrm{M}$ DNFB and $1.5 \mathrm{ml}$ of $\mathrm{pH} 10.3$ and diluted to the mark with distilled water. After 30 minute standing time at room temperature the absorbance of the yellow-colored product formed was measured at $428 \mathrm{~nm}$ against a reagent blank. A calibration curve was then constricted (Fig.1). The color reaction obeys Beer's Low from 0.05 to 2.5 $\mu \mathrm{g} / \mathrm{ml}$ of INH. The molar absorptivity, Sandell index, and limit of detection were calculated and found to be $, 2.7 \times 10^{7}, 0.005$ and 0.0098 , respectively.

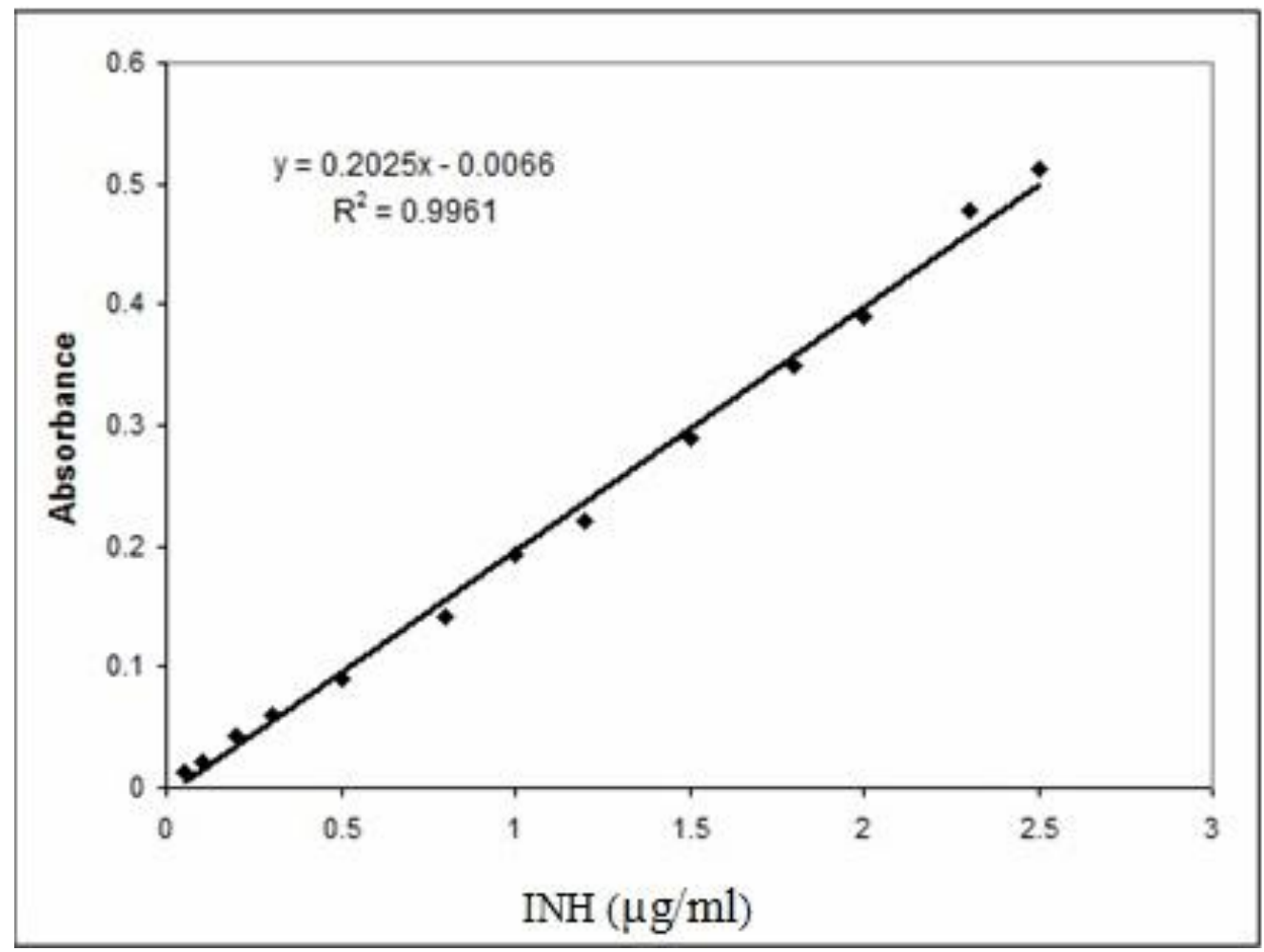

Figure 1: Calibration curve of INH using DNFB as a reagent

\section{Procedure for determination of isoniazid (INH) in pharmaceutical preparations}

Ten tablets (each tablet containing $10 \mathrm{mg}$ isoniazid) were accurately weighed and pulverized. A portion of the fine and homogenized powder weighed dissolved and transferred to $100-\mathrm{ml}$ volumetric flask and diluted to the mark with distilled water to get $100 \mu \mathrm{g} / \mathrm{ml}$ solution. From this solution $25 \mathrm{ppm}$ was prepared and used as a test solution. Aliquots of the tablets solution were taken and the procedure as described above was followed. 
Table 1: Assay of INH drug in some pharmaceutical formulations by the proposed method.

\begin{tabular}{|c|c|c|c|c|c|c|}
\hline $\begin{array}{l}\text { Procedure } \\
\text { applied }\end{array}$ & $\begin{array}{c}\text { Pharmaceutical } \\
\text { Preparation }\end{array}$ & $\begin{array}{c}\text { Drug } \\
\text { amount } \\
\text { taken } \\
(\mu \mathrm{g} / \mathrm{ml})\end{array}$ & $\begin{array}{c}\text { Recovery } \\
\% \\
\mathbf{n}=5\end{array}$ & $\begin{array}{c}\text { Drug } \\
\text { constant } \\
\text { found }\end{array}$ & $\begin{array}{c}\text { Average } \\
\text { recovery } \\
\%\end{array}$ & $\begin{array}{c}\text { Certified } \\
\text { Value } \\
\text { (mg) }\end{array}$ \\
\hline \multirow{6}{*}{$\begin{array}{l}\text { Proposed } \\
\text { method }\end{array}$} & \multirow{3}{*}{$\begin{array}{l}\text { Tablet } \\
\text { IPI, Iraq }\end{array}$} & 0.5 & 99.99 & 0.499 & \multirow{3}{*}{99.98} & \multirow{6}{*}{$10 \mathrm{mg}$} \\
\hline & & 1 & 99.97 & 0.997 & & \\
\hline & & 2 & 100.0 & 2 & & \\
\hline & \multirow{3}{*}{$\begin{array}{c}\text { Tablet } \\
\text { Macleods, India }\end{array}$} & 0.5 & 99.97 & 0.492 & \multirow{3}{*}{100.003} & \\
\hline & & 1 & 100.03 & 1.003 & & \\
\hline & & 2 & 100.01 & 1.981 & & \\
\hline
\end{tabular}

\section{Results and Discussion}

Absorption spectrum of the colored complex

Isoniazid reacts with DNFB in a basic medium $(\mathrm{pH} 10.3)$ at room temperature to give a yellow colored complex, the absorption spectrum of which shows a maximum at $428 \mathrm{~nm}$ in $[\mathrm{Fig}(2)]$.

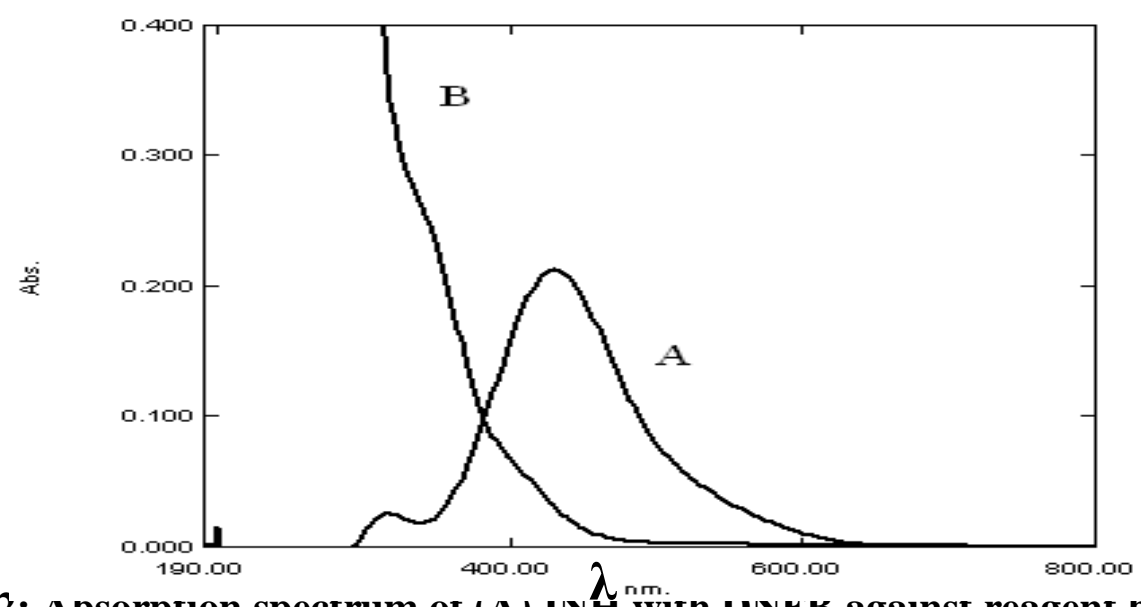

Figure 2: ADsorption spectrum or (A) INH witn UIVH B against reagent biank, and (B) reagent blank againts distilled water.

\section{Optimization of variables}

\section{Effect of $\mathrm{pH}$ and buffer solution}

The effect of $\mathrm{pH}$ on the absorption of the prodeuct was studied using different $\mathrm{pHs}$ of $\mathrm{NaOH}$ ranged from 6-11. It was found that the product formed with maximum absorption when the final $\mathrm{pH}$ of the solution was 10.3 (Table 2). Therefore different buffers with $\mathrm{pH} 10.3$ where prepared to 
examin the sensitivity. It was found that borat buffer solution with $\mathrm{pH} 10.3$ gave maximum absorpance (Table 3 ) which is used in subsequent experiments.

Table 2: Effect of $\mathrm{NaOH}$ amount on the absorbance

\begin{tabular}{|c|c|c|c|c|c|c|c|c|}
\hline $\begin{array}{c}\mathrm{NaOH} \\
1 \times 10^{-2} \mathrm{M} \\
\mathrm{ml}\end{array}$ & 0 & 0.5 & 1 & 1.5 & 2 & 2.5 & 3 & 3.5 \\
\hline Absorbance & 0.002 & 0.096 & 0.275 & 0.36 & 0.449 & 0.371 & 0.33 & 0.22 \\
\hline $\begin{array}{c}\text { Final pH of } \\
\text { the reaction } \\
\text { mixture }\end{array}$ & 6.3 & 7.3 & 9.6 & 10 & 10.3 & 10.6 & 10.77 & 11.09 \\
\hline
\end{tabular}

Table 3: Effect of buffers on the absorbance

\begin{tabular}{|c|c|c|c|c|c|c|c|}
\hline $\begin{array}{c}\text { Buffer } \\
\text { solution }\end{array}$ & $\begin{array}{c}\text { With } \\
\text { out }\end{array}$ & B1 & B2 & B3 & B4 & B5 & B6 \\
\hline Absorbance & 0.002 & 0.285 & 0.385 & 0.47 & 0.50 & 0.54 & 0.49 \\
\hline $\begin{array}{c}\text { Final pH of } \\
\text { the reaction } \\
\text { mixture }\end{array}$ & 6.3 & 9.72 & 9.95 & 9.66 & 10 & 10.3 & 10.6 \\
\hline
\end{tabular}

$\mathrm{B} 1=\mathrm{NH}_{3}-\mathrm{NH}_{4} \mathrm{Cl}$

$\left.\mathrm{B} 2=\mathrm{Na}_{2} \mathrm{CO}_{3}-\mathrm{NaHCO}_{3}\right\} \quad(\mathrm{pH}$ 10.3)

$\mathrm{B} 3=\mathrm{NaHCO}_{3}-\mathrm{NaOH}$

$\mathrm{B} 4=\mathrm{Na}_{2} \mathrm{~B}_{4} \mathrm{O}_{7}-\mathrm{NaOH}(\mathrm{pH} 10)$

$\mathrm{B} 5=\mathrm{Na}_{2} \mathrm{~B}_{4} \mathrm{O}_{7}-\mathrm{NaOH}(\mathrm{pH} 10.3)$

$\mathrm{B} 6=\mathrm{Na}_{2} \mathrm{~B}_{4} \mathrm{O}_{7}-\mathrm{NaOH}(\mathrm{pH} 10.6)$

-It was found that $1.5 \mathrm{ml}$ of buffer $\mathrm{B} 5(\mathrm{pH} 10.3)$ solution has been selected.

\section{Effect of temperature and reaction time}

Full colored product was develop rapidly after the sequence addition of the reagents and the maximum absorbance was attained after 30 minute at room temperature. The color was stable for a period of more than 60 minute after which it begun to fade.

\section{Effect of the amount of DNFB reagent}

The influence of DNFB concentration on the color intensity was studied by measuring the absorbance at the specified wavelength in the proposed procedure for solutions containing the same drug amount and 
optimum amount of the buffer but varying amount of DNFB. A volume of $2.5 \mathrm{ml}$ was found to be sufficient for full color development.

\section{Effect of order of addition}

To obtain optimum results, the order of addition of reagents was checked and was found to be immaterial.

\section{Accuracy and Precision}

The accuracy and precision of the calibration curve was established by measuring the content of INH in pure form at three different concentration levels (Table 4). The values of the relative standard deviation and mean percent recovery obtained by the proposed method can be considered to be very satisfactory.

Table 4: Precision and accuracy of the proposed method.

\begin{tabular}{|cccc||}
\hline Amount & Recovery $\%$ & Average Recovery & * RSD \\
Added $\boldsymbol{\mu} \mathbf{g} / \mathbf{m l}$ & $\mathbf{n = 5}$ & $\mathbf{\%}$ & 2.04 \\
0.3 & 100.004 & & 0.682 \\
1 & 99.99 & 99.99 & 0.289 \\
\hline 2.5 & 99.99 & & \\
\hline
\end{tabular}

*Average of five determinations.

\section{Nature of the colored product}

The molar ratio of the product formed between the drug and the DNFB reagent was established using continuous variations (Job's) method $^{(40)}$. The result indicated that the product was found in the ratio of 1:1(INH : DNFB) [Fig (3)].

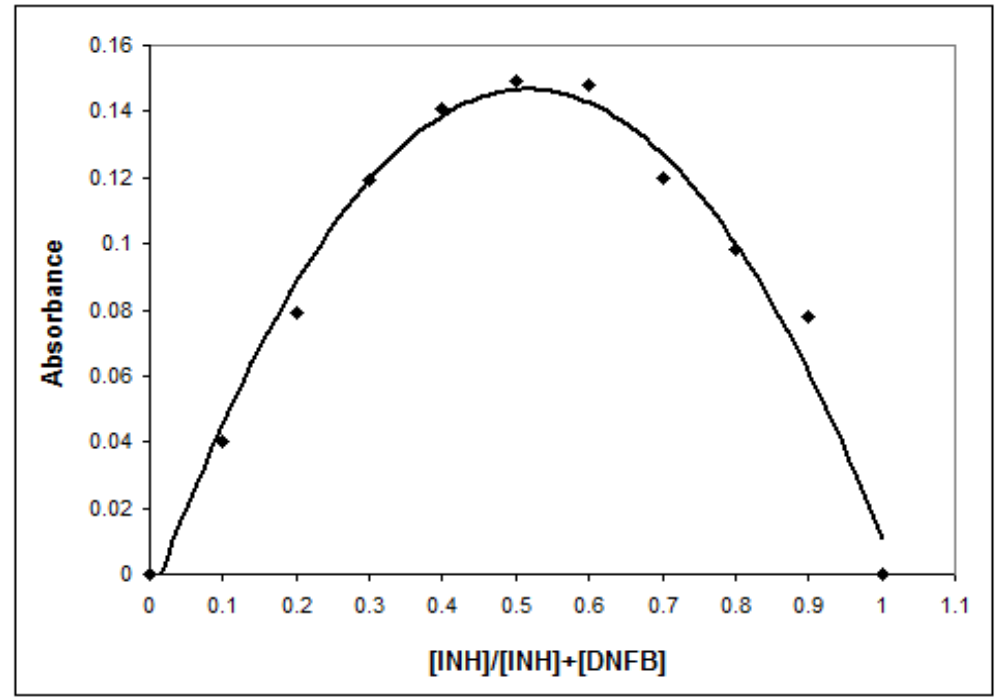

Figure 3: Job's plot of INH drug and DNFB interaction 


\section{Reaction Mechanism}

The reaction of DNFB with drug that own a free primary amine group results in the formation of colored product ${ }^{(41)}$. This reaction was first introduced by Sanger ${ }^{(42)}$ as means for determination of (DNA) sequence. Based on the job's method on the continuous variation, it was found that INH interacted with DNFB in ratio of $1: 1$ this result indicates that the reaction between the drug and the reagent used takes place only one site which was the more sterically free terminal amino group, the reaction is typical nucleophilic substitution and proceed thought an intermediate product as cited in scheme 1 .<smiles>O=[N+]([O-])c1ccc(F)c([N+](=O)[O-])c1</smiles>

DNFB<smiles>[R]N</smiles><smiles>CCC</smiles>

$$
\text { In }
$$<smiles>O=C(Nc1ccccc1)Nc1cc([N+](=O)[O-])ccc1F</smiles>

ntermediate

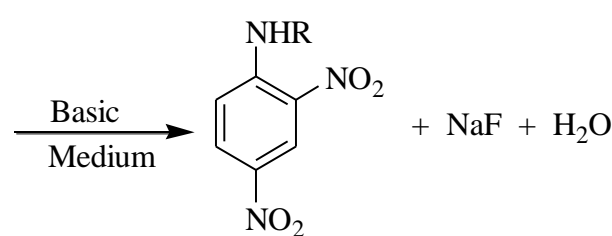

Deep yellow product<smiles>[R]N=C=Nc1ccncc1</smiles>

Isoniazid

Scheme1: Probable reaction mechanism of INH with DNFB reagent.

\section{Interferences}

The extent of interference by some excipients which often accompany pharamaceutical preparations was determined by measuring the absorbance of solutions containing $(25 \mu \mathrm{g})$ of INH and various amounts of diverse species in a final volume of $25 \mathrm{ml}$ it was found that the studied excipients do not interfere even when present in large excess. An error of $\pm 3 \%$ in the absorbance readings was considered tolerable. Typical results are given in (table 5).

Table 5: Effect of excipients for assay of $25 \mu \mathrm{g}$ isoniazid

\begin{tabular}{||c|c|c|c||}
\hline Excipients & $\begin{array}{c}\text { Amount } \\
\text { added } \mu \mathrm{g}\end{array}$ & Relative Error E\% & Recovery \% \\
\hline Glucose & $1000 \mu \mathrm{g}$ & -1.01 & 99.93 \\
\hline Lactose & $=$ & -2.02 & 98.02 \\
\hline Dextrose & $=$ & +1.01 & 100.01 \\
\hline Gum cacia & $=$ & +3.03 & 99.96 \\
\hline Starch & $=$ & +1.51 & 100.01 \\
\hline Nicotineamide & $=$ & +0.505 & 101.55 \\
\hline Pyridoxine tab.(B6) & $=$ & -1.02 & 99.99 \\
\hline Striptomycine sulphate & $=$ & +2.03 & 100.02 \\
\hline Sodium chloride & $=$ & +0.207 & 108.04 \\
\hline
\end{tabular}




\section{Application}

The proposed method was successfully applied to determine INH tablet pharmaceutical preparation. The obtain result were compared statically ${ }^{(43,44)}$ by a student's t-test for accuracy with official method at the 95\% confidence label with 5 degrees of freedom as cited (Table 6). The result showed that the experimental t-test was less than the theoretical value (2.776) indicating that there was no significant difference between the proposed method and the official method.

Table 6: Assay of INH Drug in some Pharmaceutical formulations by the proposed methods and official method.

\begin{tabular}{|c|c|c|c|c|c|c|c|}
\hline $\begin{array}{c}\text { Procedure } \\
\text { applied }\end{array}$ & $\begin{array}{l}\text { Pharmaceutical } \\
\text { preparation }\end{array}$ & $\begin{array}{c}\text { Drug } \\
\text { amount } \\
\text { taken } \\
\mu \mathrm{g} / \mathrm{ml}\end{array}$ & $\begin{array}{c}\text { Recove } \\
\text { ry \% } \\
\text { n=5 }\end{array}$ & $\begin{array}{l}\text { Drug } \\
\text { amount } \\
\text { found }\end{array}$ & $\begin{array}{c}\text { Average } \\
\text { recovery } \\
\%\end{array}$ & $\begin{array}{c}\text { Certified } \\
\text { value } \\
\text { mg }\end{array}$ & \\
\hline \multirow{6}{*}{$\begin{array}{l}\text { Proposed } \\
\text { method }\end{array}$} & \multirow{3}{*}{$\begin{array}{l}\text { Tablet } \\
\text { (IPI, Iraq) }\end{array}$} & 0.5 & 99.99 & 0.499 & \multirow{3}{*}{99.98} & \multirow{9}{*}{$10 \mathrm{mg}$} & \\
\hline & & 1 & 99.97 & 0.997 & & & t- \\
\hline & & 2 & 100.0 & 2 & & & $(t-t e s t)$ \\
\hline & \multirow{6}{*}{$\begin{array}{c}\text { Tablet } \\
\text { Macleodes, India }\end{array}$} & 0.5 & 99.97 & 0.492 & \multirow{3}{*}{100.003} & & \\
\hline & & 1 & 100.03 & 1.003 & & & \\
\hline & & 2 & 100.01 & 1.981 & & & \\
\hline \multirow{3}{*}{$\begin{array}{l}\text { Official } \\
\text { method }\end{array}$} & & 0.5 & 97.26 & 0.478 & \multirow{3}{*}{99.93} & & 0.615 \\
\hline & & 1 & 101.75 & 1.020 & & & 0.560 \\
\hline & & 2 & 100.79 & 1.996 & & & 0.858 \\
\hline
\end{tabular}

\section{Comparison of methods}

The present proposed method has been compared with other spectrophotometric methods as shown in (Table 7): 


\section{Spectrophotometic Determination of Isoniazid (INH) Using 2,4-dinitro-1- ...}

Table 7: Summary of optical characteristics and statistical data of the proposed method compared with the other method

\begin{tabular}{|c|c|c|c|c|c|}
\hline \multirow[b]{2}{*}{ Analytical Parameters } & \multicolumn{5}{|c|}{ Diazotised reagents } \\
\hline & $\begin{array}{l}\text { D-fast red } \\
\text { AL salt } \\
\text { method }^{(45)}\end{array}$ & $\begin{array}{l}\text { D-dapsone } \\
\text { method }^{(46)}\end{array}$ & $\begin{array}{c}\text { D-PNA } \\
\text { method }^{(47)}\end{array}$ & $\begin{array}{c}\text { D-SA } \\
\text { method }^{(48)}\end{array}$ & $\begin{array}{c}\text { INH-DNFB } \\
\text { proposed } \\
\text { method }\end{array}$ \\
\hline Medium of reaction & Alkaline & Alkaline & Alkaline & Alkaline & Alkaline \\
\hline$\lambda \max (\mathrm{nm})$ & 510 & 440 & 525 & 410 & 428 \\
\hline Temperature $\left(\mathrm{C}^{\circ}\right)$ & $20 \pm 3$ & $20-30$ & $\begin{array}{c}\text { room } \\
\text { temperature }\end{array}$ & $\begin{array}{c}\text { room } \\
\text { temperature }\end{array}$ & $\begin{array}{c}\text { room } \\
\text { temperature }\end{array}$ \\
\hline $\begin{array}{l}\text { Development Time } \\
\text { (min) }\end{array}$ & 10 & 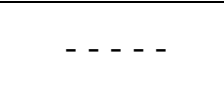 & 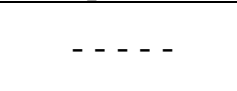 & 10 & 30 \\
\hline Stability Period (min) & 20 & 60 & 60 & 50 & 60 \\
\hline $\begin{array}{l}\text { Molar absorptivity } \times 10^{-} \\
\quad\left(\mathrm{l} \mathrm{mol}^{-1} \mathrm{~cm}^{-1}\right)\end{array}$ & 0.85 & 0.57 & 2.13 & 0.59 & $2.7 \times 10^{4}$ \\
\hline $\begin{array}{l}\text { Beer's Law range } \\
(\mathrm{ppm})\end{array}$ & $2-15$ & $0.5-20$ & $0.2-8$ & $0.2-24$ & $0.05-2.5$ \\
\hline Average recovery (\%) & $-\cdots$ & $-\cdots$ & $-\cdots$ & 99.47 & 99.99 \\
\hline RSD (\%) & 1.43 & 0.35 & 1.43 & 0.95 & 1.00 \\
\hline Stability constant $(\mathrm{K})$ & $-\ldots$ & $-\ldots-$ & $0.52 \times 10^{5} \mathrm{M}^{-1}$ & $0.90 \times 10^{9} \mathrm{M}^{-2}$ & $5.9 \times 10^{3}$ \\
\hline Correlation coefficient & 0.9993 & 0.9961 & 0.9998 & 0.9995 & 0.9961 \\
\hline Toxicity of reagent & Irritating $^{\mathrm{a}}$ & Harmful $^{\mathrm{b}}$ & Highly toxic $^{c}$ & Irritating $^{\mathrm{d}}$ & Harmful \\
\hline Analytical application & $\begin{array}{l}\text { Phamaceutral } \\
\text { preparation }\end{array}$ & $\begin{array}{l}\text { Phamaceutral } \\
\text { preparation }\end{array}$ & $\begin{array}{l}\text { Phamaceutral } \\
\text { preparation }\end{array}$ & Tablet & Tablets \\
\hline
\end{tabular}

\section{Conclusion}

An spectrophotometric method for the determination of INH was developed. The method is simple and sensitive. The statistical analysis a good agreement with those of the official British pharmacopoeia method. The color reaction is selective for INH. The method was successfully applied to the micro determination of INH either in a pure on in pharmaceutical preparations. 


\section{References}

1) Z. Song, J.Lü, T. Zhao, Talanta, 53,1171-1177, (2001).

2) J. A. Garcia-bautista. J.V. Garcia Matco. and J.M calatayua. ANAL. Lett, 31.1209, (1998).

3) J.A Tong, X.J. Dang, and L.H.Li, Electroanalysis. 9, 165, (1997).

4) S.T Sulaiman and Y.O Hameed. Anal. Chim. Acta, 206, 379, (1988).

5) F. Zhao. Y.Y. Wu. Z.Gen and H.X Wang Fenxihauaxue (Chinese), 35, 927, (1997).

6) British Pharmaocopoeia. H.M Stationary office. London, P.815, (2000).

7) The Pharmaocopoeia of People's Republic of China (Part2). Society of Pharmaocopoeia Department, Beijing, PP.235-245, (1995).

8) L. Lahuerta Zamora, J.V. Garcia Mateo. J. Martinez catatyud Anal. Chim. Acta, 81, 265, (1992).

9) I Zhang. I. Gao, X. He. X. Li, Fenxi Kexue Xucbao, 12,52, (1996).

10) N. Sadeg, N. Pertat, J. Chromatogro B. Biomed. Appl,113,675, (1996).

11) A. Defifippi, G. Piancone. Chromatographia,40,170, (1995).

12) J. Liu, W. Zhou. T.You, F. Li, E. Kang. S. Dong, Anal. Chem, 68, 3350, (1996).

13) G.M. Hanna and C.A. Lau-Cam, Ind. Pharm. 17, 975, (1991).

14) Martindal, "The Extra Pharmacopeia" $46^{\text {th }}$ ed, The Pharmaceutical Press, London, 1200, (2000).

15) C.D Poute and J.M. Nappi, Am.J. Hosp. Pharma, 33, 829-833, (1981).

16) Khuhawar My. Rind FMH. Almai KF, J, Chem, Society of Pakistan, 20 (4): 260-263, (1998).

17) S.A Gomez. Acta Farm Bonaerense, 13, 53-59, (1994).

18) Michael E. El-Kommos and Amal S. Yanni, Analyst. Vol. 113, (1988).

19) A. El-Yazigi and D-A. Rains, Pharm. Res, 19, 812-816, , (1992).

20) P.B. Issopoulos, Phar. Acta, Helv, 64, 180-183, (1989), Chem. Abst, 111, $201756 \mathrm{~K},(1989)$.

21) M.B Devani, C.J. Shishov, M.A. Patel and D.D. Bhalava, J.Pharm. Sci, 67, 661-663, (1978), Anal. Abst, 36, IE 51, (1979).

22) T.N. AL-Sabha, ph.D. Thesis, Mosul University, p85, (1997).

23) N. Erk, "Spectrose. Lett, 34, 745-761, (2001).

24) British Pharmacopoeia, Vol. 1. The Stationary office under License from the controller of Her Majesty Stationary Office. London, PP. 197, 429, (1993). 
25) O.H Lowry. H.T, Graham. F.B. Harris, M.K. Priebat, A.R Marks and V.R. Bregman, J.Pharmacol, Expti. Therap., 112, 116, (1954).

26) M.J. Kolbezen, J.W. Eckert and B.F. Bretschneider, Anal. Chem., 34, 583, (1962).

27) J.R. Couch, J.Assoc. off. Anal. Chem., 58, 599, (1975).

28) J.D. Waber. J.Pharm. Sci., 65, 105, (1976).

29) J.F, Goodwin. Clin. Chim. Acta., 21, 231, (1986).

30) Idem. Chin. Chem., 14, 1080, (1968).

31) N.F. Poole and A.E Meyer. Proe. Sol. Exp. Biod. Med., 98, 375, (1958).

32) J. A. Ryan, J. Pharm. Sci., 73, 1301, (1984).

33) P.A Lehmaun F., Anal. Chim. Acta, 54, 321, (1971).

34) P.R. Chen. and W.C. Dauterman, Anal. Biochem., 38, 224, (1970).

35) J.F.Lawrence and R.W Frei, "Chemical Derivatization in Liquid Chromatography", Elsevier, Amesterdam, (1976).

36) D.M. Barends, J.S. Blauw, C.W. Mijnsbergen, C.J.L.R. Govers and A.Hulshoff, J, Chromatog., 322-321, (1985).

37) W.Sadee and G.C.M. Beelen. "Drug Level Monitoring" Wiley, New York, (1980).

38) J.Rose "Advanced Physieo-Chemical Experments" Pitman: London, $P$ 54, (1964).

39) D.D.Perrin, buffers for $\mathrm{pH}$ and Metal ion control.

40) P.Job, "Spectrochemical Methods of Analysis" Wiley intersience: New York., P 346, (1971).

41) C.Georgion M. Kanp Paris, T.Hadjiioannon, Talanta, 38, 689, (1991).

42) F. Sanger, Biochem. J., 39, 507, (1945).

43) British Pharmacopia on CD-ROM, $3^{\text {rd }}$ Edn. Simulation Ltd, The Stationary Office, London,(2000).

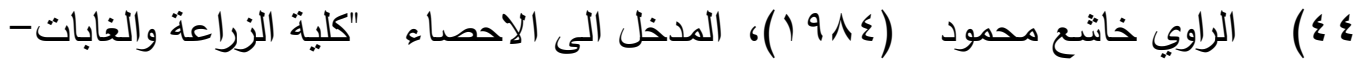

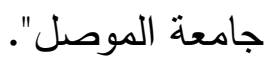

45) N.M.A.Mahfouz and K.M.Emara, "Colorimetric determination of izoniazid and its pharmaceutical formulations", Talanta, 40,10231029, (1993).

46) H.R.Vasantha, Department of studies in chemistry, University of Mysore, Manasagangotri, Mysore-570 006 , India, personal communications.

47) T.I.Younis, spectrophotometric determination of izoniazid by coupling with diazotized 4-nitroaniline-Application to tablet, "Raf.J.Sci"., in press, (2003).

48) A.N.AL-Irhayim, M.Sc.Thesis, Mosul University, p 12-31, (2004). 